\title{
DESIGN OF SPRINKLER IRRIGATION TAPERED MAIN LINE BY LINEAR PROGRAMMING
}

\author{
Hassan, A. A.
}

\section{ABSTRACT}

A mathematical linear programming model based on Microsoft Excel spreadsheet was developed to design mainline of sprinkler irrigation system. The line considered has a length of $522 \mathrm{~m}$ combined with five different nominal diameters of 3', 3-1/2", 4", 5" and 6" (internal diameter of 73.7, 85.4, 97.2, 122.3and $149.3 \mathrm{~mm}$ ) which are commercially available in the Egyptian markets. The objective function was to minimize the cost of the mainline pipe; and the constraints considered were commercial availability of diameters. The head loss calculations are based on four different head loss formulas. These are the HazenWilliams, Manning, Scobey, and Darcy-Weisbach equations. The model estimates the number of pipe unit according to the available manufacturer length. ( taken as 6 meter long). The lowest cost of 7924 US\$ was found by the Darcy Wiesbach equation followed by Manning as 8030, Hazen-Williams as 8051 and Scobey as 8385. Validity and sensitivity of the model were confirmed. The effect of land slope and inlet pressure to the system was studied. The results indicated that increasing in inlet pressure decreases the cost of the mainline. Meanwhile, the cost of the mainline is proportionally increased by increasing the up slope of the land, and inversely increases by increasing the down slope of the land.

\section{INTRODUCTION}

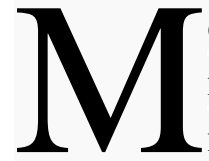
ost designers of simple pressure water delivery systems for irrigation purposes use very simple empirical pipe selection methods based on arbitrary concepts (unit head loss, velocity, and percent head loss methods), without taking into account economic criteria. These methods do not lead to an optimal solution. The designer of an irrigation system should aim to determine an adequate size and length of the main and submain pipelines so that the total annual cost is minimized.

Senior Researcher, Agric. Res., Center. Cairo, Egypt. 
For optimal design of irrigation networks, various methods have been successfully developed and applied, linear, non-linear and dynamic programming methods. Keller and Bliesner (1990) noted that the selection of economical pipe sizes is an important engineering decision; it is often given insufficient attention, especially in simple irrigation systems. In such projects, i.e. simple tapered submain lines or simple branched networks, many designers use very simple methods, including unit head loss (setting a limit on the head loss per unit length), limiting velocity, and per cent head loss (setting a limit on the friction head loss in the main line networks). Various methods have been proposed to address the question of optimal design of simple irrigation delivery systems. Keller (1975) proposed a method based on the construction of economic pipe-selection charts for determining the most economical pipe diameters in tapered submain lines or in a simple branched network. This method, as Keller and Bliesner (1990) demonstrated, resulted in designs which were less expensive. Singh et al. (2000) proposed a method based on the shortest-route algorithm for non-looping networks. This method used an equation to calculate total energy cost at each section. However, this equation has a systematic error: it takes into account the flow rate passing through each section instead of the total system flow rate (pumping discharge). On the other hand, several analytical techniques (Wu and Gitlin (1975); Solomon and Keller (1978); Valiantzas (2002)) and computer-aided design techniques (Bralts et al.,1993; Kang and Nishiyama, 1996) have been proposed, which focus on the optimization of single-diameter pipeline networks. These methods are usually based on hydraulic criteria alone and ignore economic criteria. Valiantzas ( 2003) proposed simple methods for selecting pipe sizes in tapered lateral irrigation pipelines; however, the energy cost is not considered in this suggested design procedure.

The objective of this work is to develop a mathematical linear programming optimization model that help in selecting the optimum pipe size of mainline from commercially available diameters. Minimizing the pipe cost was considered as an objective function. The solution of the problem was by Microsoft excel spread sheet applied by solver application. 


\section{Optimization model:}

Let us consider single main or submain pipeline with number of sections as given in Fig. (1). Along pipe section (i), having discharge Q(i) and length $L(i), D(i, j)$ pipe sizes, $(j=1,2,3)$ can be considered. Each pipe size $\mathrm{D}(\mathrm{i}, \mathrm{j})$ has corresponding length $\mathrm{X}(\mathrm{i}, \mathrm{j})$.

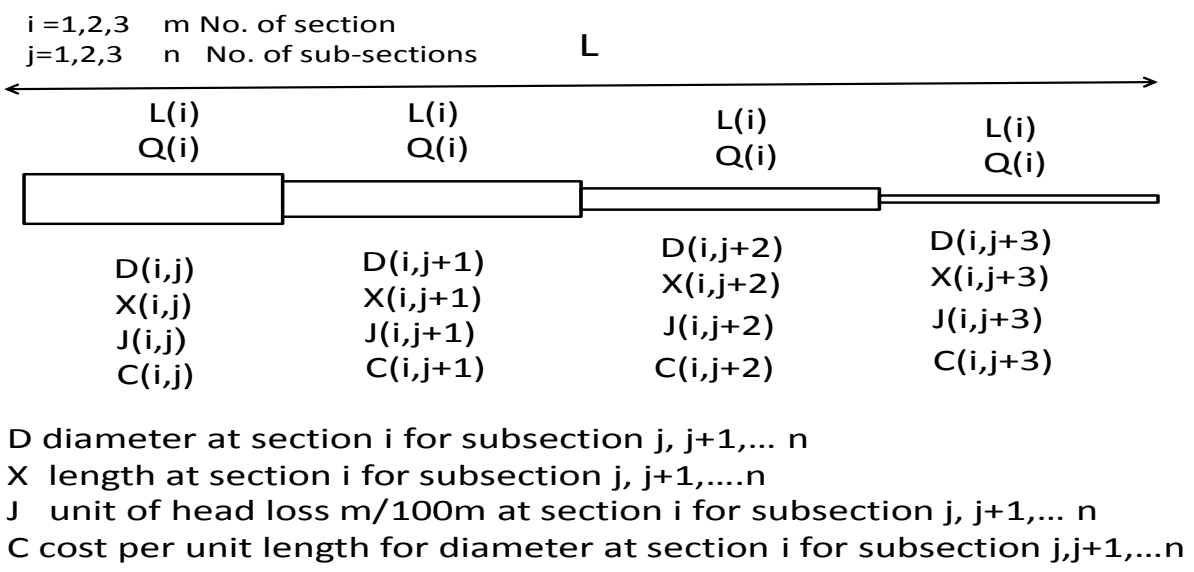

Fig. (1) description of the main pipeline parameters for design

The head loss due to friction $\mathrm{hf}(\mathrm{i}, \mathrm{j})$ along $\mathrm{X}(\mathrm{i}, \mathrm{j})$ when the discharge $\mathrm{Q}(\mathrm{i})$ and the pipe size $\mathrm{D}(\mathrm{i}, \mathrm{j})$ are computed by four different head loss equations, as Hazen Williams, Manning, Scobey and Darcy Weisbach. The general form of the friction formulas of the diameter section is as follows:

$$
h f(i, j)=\frac{K Q(i)^{a} X(i, j)}{D(i, j)^{b}}
$$

Where:

$h f(i, j) \quad$ Friction $\operatorname{loss}(\mathrm{m})$

$K, a, b \quad$ Constants

$Q(i) \quad$ Discharge cross the pipe (1/s)

$X(i, j) \quad$ Pipe length $(\mathrm{m})$

$D(i, j) \quad$ pipe diameter $(\mathrm{mm})$

Constants $\mathrm{K}$, $\mathrm{a}$ and $\mathrm{b}$ for the different friction formulas are presented in Tab. (1). Applying the loss head gradient, the pervious equation becomes: 
Table (1): Parameters and constants of the friction formulas applied

\begin{tabular}{|l|c|c|c|}
\hline \multirow{2}{*}{$\begin{array}{c}\text { The friction } \\
\text { formula }\end{array}$} & $\mathrm{K}$ & $\mathrm{a}$ & $\mathrm{b}$ \\
\cline { 2 - 4 } $\begin{array}{l}\text { Hazen - } \\
\text { Williams }\end{array}$ & $\begin{array}{c}1.22 \times 10^{10} \\
\mathrm{x}(1 / 150)^{1.852}\end{array}$ & 1.852 & 4.852 \\
\hline Manning & $1030 \times 0.009$ & 2 & $16 / 3$ \\
\hline Scobey & $0.32 \times 4.1 \times 10^{6}$ & 1.9 & 4.9 \\
\hline Darcy Wiesbach & $9.47 \times 10^{5}$ & 1.828 & 4.828 \\
\hline & $h f(i, j)=J(i, j) . \frac{X(i . j)}{100}$ \\
\hline
\end{tabular}

Where

$\mathrm{J}(\mathrm{i}, \mathrm{j}) \quad$ Head loss gradient in pipe having $\mathrm{Q}(\mathrm{i})$ and $\mathrm{D}(\mathrm{i}, \mathrm{j})(\mathrm{m} / 100 \mathrm{~m})$

The head loss hf(i,) in the $\mathrm{i}$-th pipe section is determined by summing the partial head loss along the $\mathrm{j}$ diameter, consequently,

$$
h f(i)=\sum_{j=1}^{j=n} J(i, j) \cdot \frac{X(i, j)}{100}
$$

The model described in this paper assumed that the layout of the field and pipes, as well as the discharge loads have already been determined. It is also assumed that the water is supplied from the regional main pipeline which provides changeable pressure head. The pressure head hu(i) required at the inlet to the laterals are computed by the following:

$$
h u(i)=h s+\frac{3}{4} h f+h r \pm \frac{\Delta z}{2}
$$

Where:

hu(i) Pressure head required at the lateral inlet (m)

hs $\quad$ Sprinkler operating pressure head (m)

hf Pressure head loss in lateral pipe (m)

$\mathrm{hr} \quad$ Riser height (m)

$\Delta \mathrm{z} \quad$ Elevation difference along the lateral (m) 
The total head at the lateral inlet $\mathrm{Hu}(\mathrm{i})$ is determined by adding the surface elevation zi between the lateral and the submain and the local head loss $\mathrm{k}$ in the take off, where:

$$
H u(i)=h u(i)+z i+k
$$

\section{The objective function:}

The objective function is to obtain, under certain limitations called constraints, a solution of the most economic cost of design and operating sprinkler irrigation system. The minimum requirement of minimum total annual cost, expressed mathematically is defined as the objective function. The cost per unit length for pipe with diameters $D(i, j)$ is $C(i, j)$. The cost along $\mathrm{X}(\mathrm{i}, \mathrm{j})$ is therefore, $\mathrm{C}(\mathrm{i}, \mathrm{j})$ multiplied by $\mathrm{X}(\mathrm{i}, \mathrm{j})$. Thus, the cost $\mathrm{C} 1(\mathrm{i})$ along the $\mathrm{i}$-th pipe section is computed from :

$$
C 1(i)=\sum_{j=1}^{m} C(i, j) \cdot X(i, j)
$$

Therefore, the total cost of the system mainline is determined by summing the partial costs of the i-th pipe sections as,

$$
C_{T}=\sum_{i=}^{m} \sum_{j=1}^{n} C(i, j) \cdot X(i, j)
$$

The previous equation when minimized is the objective function of the herein model.

\section{The constraints:}

Certain constraints are imposed on the objective function depending on the type of the function. The first and the most important is the requirement of the pressure head at each node (i) as recommended by Benami and Ofen 1984, which should be at least $\mathrm{Hu}(\mathrm{i})$ as:

$$
\text { Ho }-\sum_{i=1}^{m} \sum_{j=1}^{n} \frac{X(i, j) \cdot J(i, j)}{100} \geq H u(i)
$$

Where:

Ho Net available pressure head at the inlet of the main pipe.

$X \quad$ length

$J \quad$ Head loss gradient $(\mathrm{m} / 100 \mathrm{~m})$

$i \quad$ Section number $(\mathrm{i}=1,2,3 \ldots \mathrm{m})$

$j \quad$ Diameter subsection number $(\mathrm{j}=1,2,3 \ldots \mathrm{n})$ 
When a pump supplies the irrigation water, Ho is a variable having predetermined values. It follows that the optimum Ho satisfied the requirement of minimum cost for the pipe system. The second constraint states that each pipe section $\mathrm{L}(\mathrm{i})$ is the sum of the sub pipe section $\mathrm{X}(\mathrm{i}, \mathrm{j})$ having diameters $\mathrm{D}(\mathrm{i} . \mathrm{j})$, equal the total length $\mathrm{L}(\mathrm{i})$ as:

$$
\sum_{j=1}^{n} X(i, j)=L(i)
$$

$X(i, j)$ could be replaced by the number of pipe unit length $N$ multiplied by the manufacturer pipe unit length which is considered $6 \mathrm{~m}$ in the study. The previous constraint is true until $\mathrm{N}$ is an integer number, as:

$$
\sum_{j=1}^{n} 6 N(i, j)=L(i) \quad \text { Where } \quad N(i, j)=\text { int eger }
$$

The next constraint states the mainline total length $(\mathrm{L})$ is the sum of the mainline sub-sections L(i) as:

$$
L=\sum_{i=1}^{n} L(i)
$$

The fourth constraint involves the non- negativity of the pipe lengths, as:

$$
N(i, j) \geq 0 \text { and } L(i) \geq 0
$$

Finally, solving for the optimum pipe size of sprinkler mainline and the corresponding lengths, the objective function is formulated as:

$$
\text { Min . } C_{T}=6 \sum_{i=1}^{m} \sum_{j=1}^{n} C(i, j) \times N(i, j)
$$

\section{Case study:}

A procedure of applying linear programming technique for design main line is proposed by a case study to demonstrate how the model selects the optimum pipe sizes for the minimum cost. Let us considerer mainline serves a governmental farm includes 6 fields each 6.17 feddan $(180 \mathrm{~m} \mathrm{x}$ $144 \mathrm{~m}$ ) at area where the consumptive use by the crop is $5 \mathrm{~mm} /$ day. Each field irrigated by two hand move laterals. The lateral served by 8 sprinklers and the sprinkler flow rate is $1.6 \mathrm{~m}^{3} / \mathrm{h}$ operated at $30 \mathrm{~m}$ pressure head. The irrigation set time is 6 hours per day. The distance between lateral is $18 \mathrm{~m}$ and the distance between sprinklers is $18 \mathrm{~m}$ and the system efficiency is $85 \%$. According to these inputs, the application rate is $4.94 \mathrm{~mm} / \mathrm{h}$ and the available moisture in the root zone is about 25 
$\mathrm{mm}$ and the irrigation interval is 5 days. Fig.(2) depicts PVC mainline buried $0.6 \mathrm{~m}$ and having a downward slope of $2 \%$ runs though the center of a field $522 \mathrm{~m}$ long. Along its length the mainline has 15 take-off, spaced $36 \mathrm{~m}$ apart serving a total of 60 lateral settings. six PVC hand moved level laterals are operated simultaneously along the mainline.

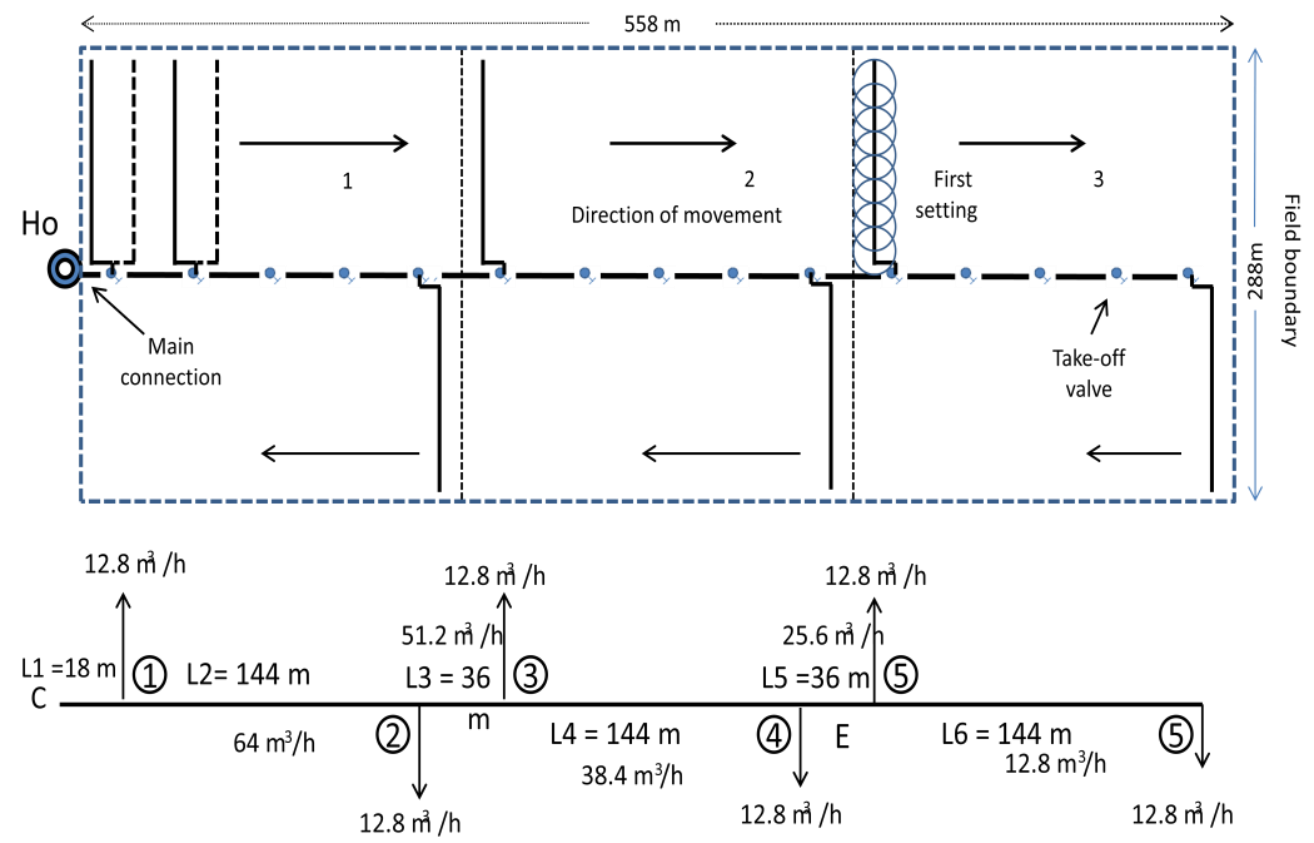

Fig. (2 ) Schematic diagram of the system considered in the case studied

Fig. (2). Shows the sequence of operation, three lateral are started at field 1,2 and 3 at the same time anther three lateral next to the main line started and gradually moved back to their starting position. The total length of the mainline is $522 \mathrm{~m}$ combined with five PVC commercial available nominal diameters of 3", 3-1/2", 4" ,5" and 6" ( internal diameter of $73.7 \mathrm{~mm}, 85.4 \mathrm{~mm}, 97.2 \mathrm{~mm}, 122.3 \mathrm{~mm}$ and $146 . \mathrm{mm}$ respectively, (the source is USplastic. Com according to January,2016 price list). The cost per/meter of the pipe are $7.9 \mathrm{US} \$ / \mathrm{m}, 11.4 \mathrm{US} \$ / \mathrm{m}$, $17.1 \$ / \mathrm{m}, 21.9$ US $\$ / \mathrm{m}$ and $33.1 \mathrm{US} \$ / \mathrm{m}$ respectively. Among the application four different head loss equations were tested. These are Hazen Williams, Manning, Scobey and Darcy Weisbach. Thirty takes- off spaced $36 \mathrm{~m}$ apart are installed in the mainline. Six 3" PVC laterals $135 \mathrm{~m}$ length is running on zero level land. The model discussed assumed that the layout of the fields as well as the discharge loads has already been 
determined. It is also assumed that the water supplied from the regional main pipe line could provide changeable pressure head. The allowable head losses on the mainline taken as $2 \mathrm{~m} / 100 \mathrm{~m}$. According to these inputs:

A- The length constraints:
$6 \sum_{j=1}^{5} N(1, j)=L(1)$
$6 \sum_{j=1}^{5} N(2, j)=L(2)$
$6 \sum_{j=1}^{5} N(3, j)=L(3)$
$6 \sum_{j=1}^{5} N(4, j)=L(4)$
$6 \sum_{j=1}^{5} N(5, j)=L(5)$
$6 \sum_{j=1}^{5} N(6, j)=L(1)$

\section{B- The hydraulic constraints:}

$$
\begin{aligned}
& H o \pm \Delta o-6 \sum_{j=1} N(i, j) \times J(1, j) \geq H u(1) \pm \Delta(1) \\
& H o \pm \Delta o-6\left(\sum_{j=1}^{j=5} N(1, j) \times J(1, j)+\sum_{j=1}^{j=5} N(2, j) \times J(2, j)\right) \geq H u(2) \pm \Delta(2) \\
& H o \pm \Delta o-6\left(\sum_{j=1}^{j=5} N(1, j) \times J(1, j)+\sum_{j=1}^{j=5} N(2, j) \times J(2, j)+\sum_{j=1}^{j=5} N(3, j) \times J(3, j)\right) \geq H u(3) \pm \Delta(3) \\
& H o+\Delta o-6\left|\begin{array}{l}
\sum_{j=1}^{j=5} N(1, j) \times J(1, j)+\sum_{j=1}^{j=5} N(2, j) \times J(2, j)+ \\
j=5 \\
\sum_{j=1} N(3, j) \times J(3, j)+\sum_{j=1}^{j=5} N(3, j) \times J(3, j)
\end{array}\right| \geq H u(4) \pm \Delta(4) \\
& H o \pm \Delta o-6\left|\begin{array}{cl}
\sum_{j=1}^{j=5} N(1, j) \times J(1, j)+\sum_{j=1}^{j=5} N(2, j) \times J(2, j)+ & \mid \\
\sum_{j=1} N(3, j) \times J(3, j)+\sum_{j=1} N(4, j) \times J(4, j)+\sum_{j=1}^{j=5} N(5, j) \times J(5, j)
\end{array}\right| \geq H u(5)+\Delta(5) \\
& \left.H o \pm \Delta o-6 \mid \begin{array}{ll}
\sum_{j=1}^{j=5} N(1, j) \times J(1, j)+\sum_{j=1}^{j=5} N(2, j) \times J(2, j)+\sum_{j=1}^{j=5} N(3, j) \times J(3, j)+ \\
j=5 \\
\sum_{j=1}^{j=5} N(4, j) \times J(4, j)+\sum_{j=1}^{j=5} N(5, j) \times J(5, j)+\sum_{j=1}^{j} N(6, j) \times J(6, j)
\end{array}\right)
\end{aligned}
$$


Where:

$\Delta \mathrm{o} \quad$ Elevation head at the mainline inlet point (o) or at the pump (m)

$\mathrm{Hu}(\mathrm{i}) \quad$ Pressure head required at take-off of section $(\mathrm{i}=1,2,3,4)$

$\Delta(\mathrm{i}) \quad$ Elevation head at section $(\mathrm{i}=1,2,3,4)$

$\mathrm{N}(\mathrm{i}, \mathrm{j}) \quad$ Integer No. of pipe unit $(6 \mathrm{~m})$ for section $\mathrm{i}$ and subsection $\mathrm{j}$,

\section{RESULTS AND ANALYSIS}

The model described earlier (objective function, constraints and the integer variable) was written on Excel spread sheet and solved by solver application. The linear programming by solver applied simplex and dual simplex methods, the problem include integer variables constraints, the branch and bound method is implemented.

According to the case study inputs which: head loss gradient of about $2 \mathrm{~m} / 100$ of the mainline length, No. of nods nodes (7), No of sections (6) and their length, No. of available pipes and their prices $\$ / \mathrm{m}$, No. of lateral operated simultaneously (6), land slope (down slope $2 \%$ for the mainline and zero slope for laterals), sprinkler discharge $\left(1.6 \mathrm{~m}^{3} / \mathrm{h}\right)$ and the operating pressure (3 bar). The results presented in Table (2).

Table (2): The model results for minimum cost of the mainline pipes.

\begin{tabular}{|c|c|c|c|c|c|c|c|c|}
\hline \multirow{2}{*}{ Section } & \multirow{2}{*}{$\begin{array}{c}\text { Length } \\
\mathrm{m}\end{array}$} & \multirow{2}{*}{$\begin{array}{l}\text { Discharge } \\
\mathrm{m}^{3} / \mathrm{h}\end{array}$} & \multirow{2}{*}{$\begin{array}{l}\text { Diameter } \\
\mathrm{mm}\end{array}$} & \multicolumn{4}{|c|}{ Number of pipe units per Method } & \multirow{2}{*}{$\begin{array}{l}\text { Price } \\
\text { US } \$ / m\end{array}$} \\
\hline & & & & Hazen & Darcy & Scobey & Manning & \\
\hline \multirow{2}{*}{ C- 1} & \multirow{2}{*}{18} & \multirow{2}{*}{76.8} & 146.3 & 1 & 1 & 1 & 1 & 33.1 \\
\hline & & & 122.3 & 2 & 2 & 2 & 2 & 21.9 \\
\hline $1-2$ & 144 & 64.0 & 122.3 & 24 & 24 & 24 & 24 & 21.9 \\
\hline $2-3$ & 36 & 51.2 & 122.3 & 6 & 6 & 6 & 6 & 21.9 \\
\hline \multirow{3}{*}{$3-4$} & \multirow{3}{*}{144} & \multirow{3}{*}{38.4} & 122.3 & 3 & 1 & 1 & - & 21.9 \\
\hline & & & 97.2 & 8 & 8 & 19 & 13 & 17.1 \\
\hline & & & 85.5 & 13 & 15 & 4 & 11 & 11.4 \\
\hline \multirow{2}{*}{$4-5$} & \multirow{2}{*}{36} & \multirow{2}{*}{25.6} & 85.5 & 5 & 5 & 6 & 5 & 11.4 \\
\hline & & & 73.3 & 1 & 1 & & 1 & 7.9 \\
\hline $5-6$ & 144 & 12.8 & 73.3 & 24 & 24 & 24 & 24 & 7.9 \\
\hline \multicolumn{4}{|c|}{ Total cost of pipe $\$$} & 8051 & 7924 & 8384 & 8030 & \\
\hline
\end{tabular}


The hydraulic parameter of the design by linear programming of the mainline illustrated in Tab. (3a) and Tab. (3b). The velocity limits within the system is $0.83 \mathrm{~m} / \mathrm{s} \leq \mathrm{V} \leq 1.86 \mathrm{~m} / \mathrm{s}$ and the head loss gradient was 0.6 $\mathrm{m} / 100 \mathrm{~m} \leq \mathrm{J} \leq 4 \mathrm{~m} / 100 \mathrm{~m}$. These could be acceptable in design main and submain line pipes in sprinkler irrigation systems

Table (3a): Linear programming hydraulic results of the mainline by Hazen Williams and Darcy Wisbach

\begin{tabular}{|c|c|c|c|c|c|c|c|c|c|c|c|c|}
\hline \multirow[b]{2}{*}{. } & \multirow[b]{2}{*}{ 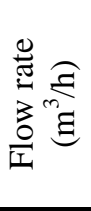 } & \multirow[b]{2}{*}{ 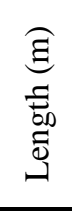 } & \multicolumn{5}{|c|}{ Hazen } & \multicolumn{5}{|c|}{ Darcy } \\
\hline & & & $\begin{array}{l}\tilde{0} \cdot \mathscr{\Xi} \\
\dot{0} \cdot \ddot{z}\end{array}$ & 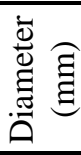 & $-\frac{\widehat{\Xi}}{\stackrel{8}{8}}$ & 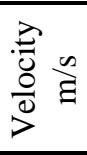 & 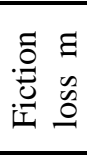 & 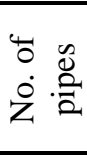 & 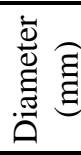 & $-\stackrel{\text { छ }}{\stackrel{8}{ٍ}}$ & $\begin{array}{l}\stackrel{\overrightarrow{0}}{0} \\
\frac{0}{0} \\
>\end{array}$ & 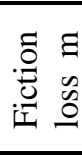 \\
\hline \multirow{2}{*}{ C -1} & \multirow{2}{*}{76.8} & \multirow{2}{*}{18} & 1 & 146 & 0.91 & 1.27 & 0.06 & 1 & 146 & 0.89 & 1.27 & 0.05 \\
\hline & & & 2 & 122 & 2.26 & 1.82 & 0.27 & 2 & 122 & 2.13 & 1.82 & 0.25 \\
\hline $1-2$ & 64.0 & 144 & 24 & 122 & 1.61 & 1.51 & 2.31 & 24 & 112 & 1.53 & 1.51 & 2.2 \\
\hline $2-3$ & 51.2 & 36 & 6 & 122 & 1.06 & 1.21 & 0.38 & 6 & 122 & 1.02 & 1.21 & 0.37 \\
\hline \multirow{3}{*}{$3-4$} & \multirow{3}{*}{38.4} & \multirow{3}{*}{144} & 3 & 122 & 0.62 & .91 & 0.11 & 1 & 122 & 0.6 & 0.91 & 0.04 \\
\hline & & & 8 & 97 & 1.91 & 1.44 & 0.92 & 8 & 97 & 1.82 & 1.44 & 0.87 \\
\hline & & & 13 & 85 & 3.57 & 1.86 & 2.79 & 15 & 85 & 3.38 & 1.86 & 3.05 \\
\hline \multirow{2}{*}{$4-5$} & \multirow{2}{*}{25.6} & \multirow{2}{*}{36} & 5 & 85 & 1.69 & 1.24 & 0.51 & 5 & 85 & 1,61 & 1.24 & 0.48 \\
\hline & & & 1 & 73 & 3.47 & 1.67 & 0.21 & 1 & 73 & 3.3 & 1.67 & 0.2 \\
\hline $5-6$ & 12.8 & 144 & 24 & 73 & 0.96 & 0.83 & 1.39 & 24 & 73 & 0.93 & 0.83 & 1.34 \\
\hline \multicolumn{3}{|c|}{ Total } & 90 & & & & 8.94 & 90 & & & & 8.85 \\
\hline
\end{tabular}

Table (3a): Linear programming hydraulic results of the mainline by Manning and Scobey

\begin{tabular}{|c|c|c|c|c|c|c|c|c|c|c|c|c|}
\hline \multirow[b]{2}{*}{.气 } & \multirow{2}{*}{ 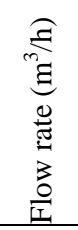 } & \multirow[b]{2}{*}{ 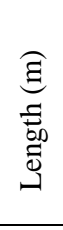 } & \multicolumn{5}{|c|}{ Manning } & \multicolumn{5}{|c|}{ Scobey } \\
\hline & & & $\begin{array}{l}\dot{0} . \tilde{O} \\
\dot{0} \cdot \mathscr{Z}\end{array}$ & 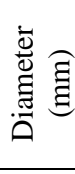 & 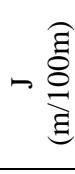 & 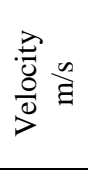 & 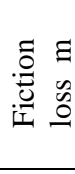 & $\begin{array}{l}\tilde{0} \\
\dot{0}:\end{array}$ & 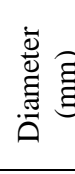 & 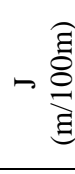 & 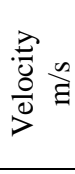 & 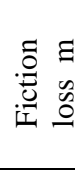 \\
\hline \multirow{2}{*}{ C -1} & \multirow{2}{*}{76.8} & \multirow{2}{*}{18} & 1 & 146 & 0.85 & 1.27 & 0.05 & 2 & 146 & 1.08 & 1.28 & 0.13 \\
\hline & & & 2 & 122 & 2.21 & 1.82 & 0.27 & 1 & 122 & 2.6 & 1.82 & 0.16 \\
\hline $1-2$ & 64.0 & 144 & 24 & 122 & 1.54 & 1.51 & 2.21 & 24 & 122 & 1.84 & 1.51 & 2.65 \\
\hline $2-3$ & 51.2 & 36 & 6 & 122 & 0.98 & 1.21 & 0.35 & 6 & 122 & 1.21 & 1.21 & 0.43 \\
\hline \multirow{3}{*}{$3-4$} & \multirow{3}{*}{38.4} & \multirow{3}{*}{144} & & & & & & 1 & 122 & 0.7 & .91 & 0.04 \\
\hline & & & 13 & 85 & 1.88 & 1.44 & 1.47 & 19 & 97 & 2.15 & 1.44 & 2.45 \\
\hline & & & 11 & 73 & 3.74 & 1.86 & 2.47 & 4 & 85 & 4.00 & 1.86 & 0.97 \\
\hline \multirow{2}{*}{$4-5$} & \multirow{2}{*}{25.6} & \multirow{2}{*}{36} & 5 & 85 & 1.66 & 1.24 & 0.5 & & & & & \\
\hline & & & 1 & 73 & 3.67 & 1.67 & 0.22 & 6 & 85 & 1.87 & 1.24 & 0.67 \\
\hline $5-6$ & 12.8 & 144 & 24 & 73 & 0.92 & 0.83 & 1.32 & 24 & 73 & 1.04 & 0.83 & 1.49 \\
\hline \multicolumn{3}{|c|}{ Total } & 90 & & & & 8.86 & 90 & & & & 8.99 \\
\hline
\end{tabular}


Effect of land slope and inlet pressure head on mainline cost:

The inlet pressure head influenced the total cost of the mainline. It is well known that the down slope increase the pressure head due to the gravitational effect which allow increasing in allowable pressure loss used in design the pipe size. This interpreted to small pipe size. The effect of both land slope and inlet pressure on mainline cost was studied. The land slope changed from $-2 \%$ to $2 \%$.and the inlet pressure head from 50 to 70 $\mathrm{m}$ as shown in Fig. (3). The result indicated that the cost of mainline decreased by increasing the inlet pressure but with different degrees depending mainly on the land slope. The cost of the mainline was decreased by $30.8 \%$ at zero level slope due to increase the mainline inlet pressure from $50 \mathrm{~m}$ to $70 \mathrm{~m}$. In case of upslope conditions the cost is decreased by $47.5 \%, 41.8 \%, 36.3 \%$ and $33.7 \%$ due to change of inlet pressure from $50 \mathrm{~m}$ to $70 \mathrm{~m}$ at the upslope of $2 \%, 1.5 \%, 1 \%$ and $0.5 \%$ respectively. The results indicated moderate decrease due to change of inlet pressure ranged between $28.1 \%$ and $21.5 \%$ in case of down slope lands ranged between $-.5 \%$ and $-2 \%$ at the same limit of pressure inlet to the main line.

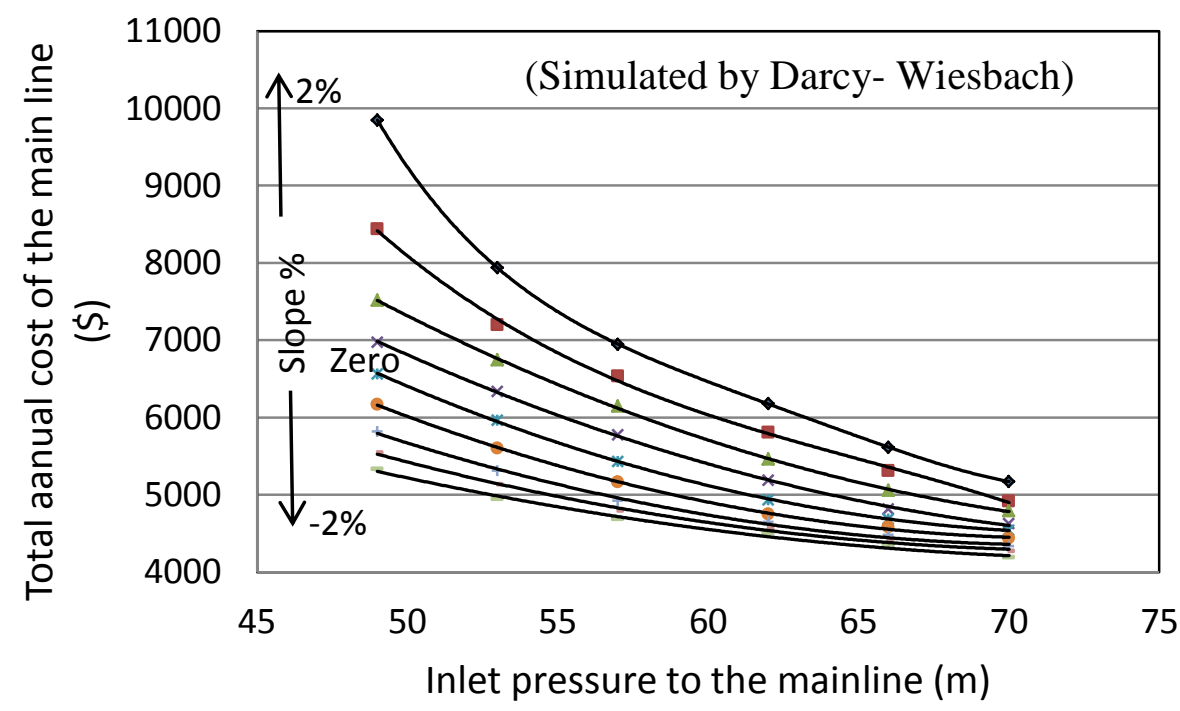

Fig.(3) Effect of land slope and inlet pressure on mainline total cost 


\section{Checking head at the terminal nodes (sprinklers)}

In order to insure the arrival of water at the last sprinkler, calculations are made to check heads at the terminal sprinklers on the laterals. If the calculated pressure head at these point is greater than or equal the sprinkler operating pressure (hs) that mean the system is designed correctly. The pressure head at last sprinkler (hs) on laterals for the different settings at slope between $-2 \%$ and $2 \%$ and inlet pressure head (Ho) between $35 \mathrm{~m}$ and $55 \mathrm{~m}$ are given in Tab.(4). As shown none of the sprinkler pressure head at any setting is less $30 \mathrm{~m}$ (hs) even by the different methods applied to estimate the head losses. Regardless of the slope value and direction and the friction formula, the terminal pressure value is about $31 \mathrm{~m}$. These results verified the model logic, algorism and sensitivity to design the mainline by linear programming.

Table (4): Pressure head at the terminal sprinkler at each lateral setting

\begin{tabular}{|c|c|c|c|c|c|c|c|c|c|}
\hline Method & slope & $\mathrm{Hc}$ & $\mathrm{hs}(1)$ & $\mathrm{hs}(2)$ & $\mathrm{hs}(3)$ & $\mathrm{hs}(4)$ & $\mathrm{hs}(5)$ & $\mathrm{hs}(6)$ & $\mathrm{h}_{\mathrm{f}} / \mathrm{HC}$ \\
\hline \multirow{5}{*}{ Darcy } & $2 \%$ & 54.75 & 51.34 & 46.26 & 44.68 & 36.82 & 35.32 & 31.10 & 0.1907 \\
\cline { 2 - 9 } & $0 \%$ & 44.31 & 41.26 & 39.06 & 38.20 & 33.22 & 32.44 & 31.10 & 0.2356 \\
\cline { 2 - 9 } & $-2 \%$ & 33.87 & 31.25 & 31.93 & 32.29 & 31.11 & 31.15 & 32.69 & 0.2613 \\
\hline \multirow{5}{*}{ Hazen } & $2 \%$ & 54.76 & 51.31 & 46.12 & 44.89 & 36.76 & 35.44 & 31.17 & 0.1894 \\
\cline { 2 - 10 } & $0 \%$ & 44.32 & 41.23 & 38.92 & 38.41 & 33.16 & 32.56 & 31.17 & 0.2340 \\
\cline { 2 - 9 } & $-2 \%$ & 33.88 & 31.23 & 31.80 & 32.14 & 31.10 & 31.11 & 32.60 & 0.2638 \\
\hline \multirow{5}{*}{ Scobey } & $2 \%$ & 54.74 & 51.32 & 46.23 & 45.01 & 36.65 & 35.33 & 31.13 & 0.1902 \\
\cline { 2 - 9 } & $0 \%$ & 44.30 & 41.24 & 39.03 & 38.53 & 33.05 & 32.45 & 31.13 & 0.2350 \\
\cline { 2 - 9 } & $-2 \%$ & 33.86 & 31.24 & 31.91 & 32.28 & 31.11 & 31.12 & 32.68 & 0.2616 \\
\cline { 2 - 9 } & $2 \%$ & 54.79 & 51.25 & 45.72 & 44.57 & 36.88 & 35.49 & 31.12 & 0.1902 \\
\hline & $-2 \%$ & 33.91 & 31.27 & 31.50 & 31.79 & 31.11 & 31.16 & 32.55 & 0.2653 \\
\hline
\end{tabular}


Another factor could be used to verify the acceptability of the model which is the ratio between the total head loss along the system and the system inlet pressure (hf/Ho). This ratio for the acceptable hydraulic design should be less than 0.3 (1991) (شارلى، (4). The results indicated in Tab. (4) confirmed this condition.

\section{CONCLUSSIONS}

The paper presented a mathematical development of linear programming technique to design mainline of sprinkler irrigation system based on minimizing the pipe cost. The algorithm of the hydraulic fiction losses was based on Darcy- Weisbach, Hasen Williams, Manning and Scobey formulas. The developed model used available pipes diameter in the market. Analyses were performed based on numerical example to design a mainline design. Results showed that least cost of the mainline pipes was given by applying Darcy- Weisbach as 7924 US\$ followed by Manning formula that increased by $1.34 \%$. Hazen Williams gives the second higher cost than Darcy by $1.6 \%$. The cost by Scobey is increased by $5.81 \%$. The influences of land slope and inlet pressure to the system were studied. Increasing the pressure at the pump in the down slope lands leads to steady decrease in the cost of the mainline. Over zero slope the cost of the mainline decreased proportionally to increasing the inlet pressure especially in higher up slope conditions. In general, the mainline cost decreased by increasing the inlet pressure in case of upslope conditions, meanwhile almost no influence in down slope lands. This is true when the system is operated at minimum allowable pressure head. In case of inlet pressure higher than the minimum allowable on down slope conditions, the decrease is relatively moderate. Results indicated reduction about $30.8 \%$ due to change in inlet pressure from 70 to $50 \mathrm{~m}$ at leveled land. The influence of inlet pressure in case of up slope land is relatively high. The cost reduces by almost half due to slope change by $2 \%$. The validity and sensitivity of the model were confirmed by calculating the pressure at the terminal sprinkler (which should be at least the operating pressure hesd) at different slope values from $-2 \%$ to $2 \%$. 
The results indicated that none of pressure head at the terminal sprinklers less that 3 bar. Hydraulic parameters limits given by the model such as water velocity inside the pipe sections, head loss to inlet pressure ratio (hf/HC), head losses gradient show acceptable limit values. The velocity limits is $0.82 \mathrm{~m} / \mathrm{s} \leq \mathrm{V} \leq 1.86 \mathrm{~m} / \mathrm{s},(\mathrm{hf} / \mathrm{HC}) \leq 0.3$ and the head loss gradient is $0.82 \mathrm{~m} / 100 \mathrm{~m} \leq \mathrm{J} \leq 4 \mathrm{~m} / 100 \mathrm{~m}$.

\section{REFERENCES}

Bralts V.F., S.F. Kelly, W.H. Shayya and L. J. Segerlind, (1993). Finite elements analysis of microirrigation hydraulics using virtual emitter systems. ASAE, 36 (3):717-725.

Benami, I. and A. Ofen 1984. Irrigation Engineering, Irrigation Engendering Scientific Publications (IESP), Haifa, Israel. 257 Pp.

Kang V, Nishiyama S. 1996. Design of micro irrigation submain units. Journal of Irrigation and Drainage Engineering 122(2): 83-89.

Keller J, Bliesner RD. 1990. Sprinkle and Trickle Irrigation. Van Nostrand Reinhold, Chapman and Hall: New York.

Keller J. 1975. Economic pipe selection chart. In Proceedings, ASCE Irrigation and Drainage Division Special Conference, 13-15 Aug. 1968, Utah State University, Logan, Utah.

Singh A, Singh RP, Mahar PS, Singh KK. 2000. Optimal design of tapered microirrigation submain manifolds. Journal of Irrigation and Drainage Engineering 126(6): 371-374.

Solomon K, Keller J. 1978. Trickle irrigation uniformity and efficiency. Journal of the Irrigation and Drainage Division 104(3): 293-306.

Valiantzas JD. 2002. Continuous outflow variation along irrigation laterals: effect of the number of outlets. Journal of Irrigation and Drainage Engineering ASCE 128(1): 34-42. 
Valiantzas JD. 2003. Inlet pressure, energy cost and economic design of tapered irrigation sub mains. Journal of Irrigation and Drainage Engineering ASCE 129(2): 100-107.

Wu IP, Gitlin HM. 1975. Energy gradient line for drip irrigation laterals. Journal of Irrigation and Drainage Engineering 101(4): 323-326.

$$
\text { شارلى شكرى سكلا . " هندسة الرى و الصرف " . دار المعارف ـ1991. }
$$

تصميم الخط الرئيسى للرى بالرش المتعدد الاقطار

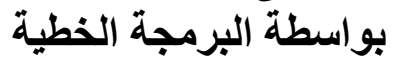

عزة عبد الفتاح حسن

اجريت هذه الدراسة لتصميم الخط الرئيسى لنظام الرى بالرش متعدد الاقطار لتقليل تكاليف

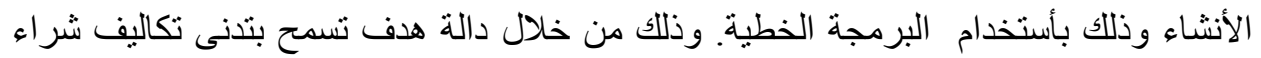

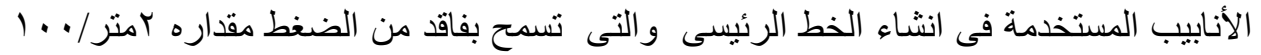

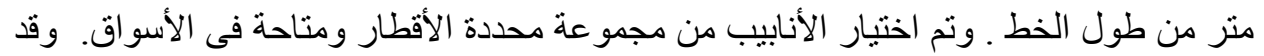

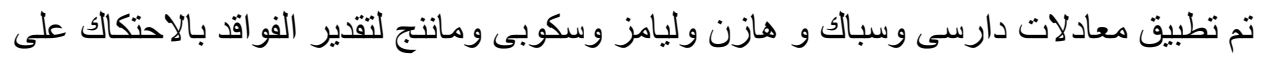

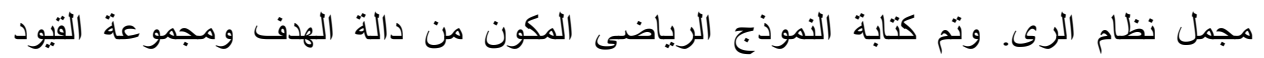

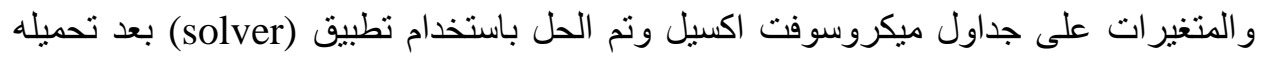
على هذه الجداول. ومن خلال مثال عددى تم تطبيق النموذج الرياضى وكذلك التحقق من صلاحيته وذللك من خلال التحقق من حدود الفو اقد المسموح بها وسرعات الترات المياه في القطاعات

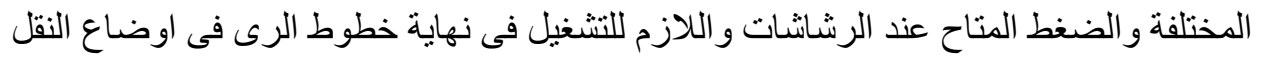

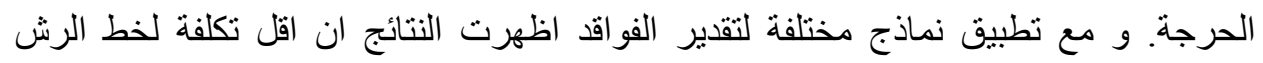

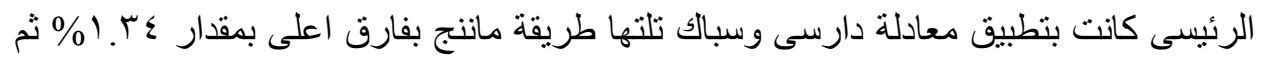

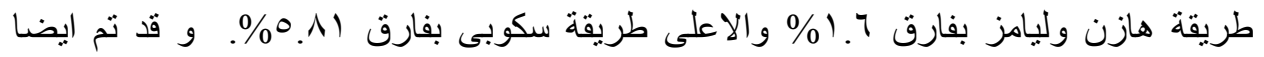

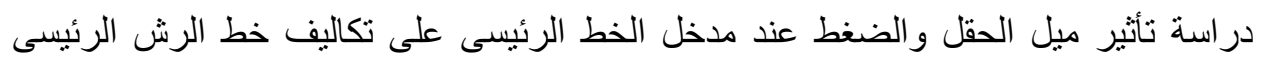

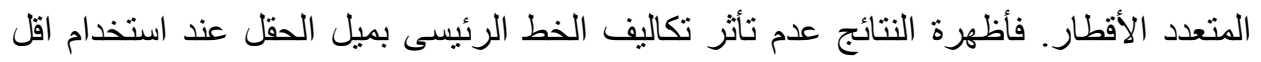

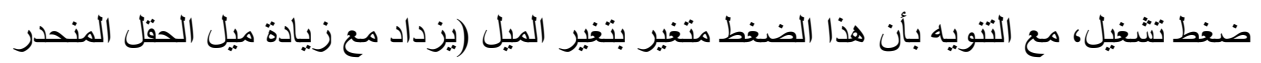
الى اعلى ويقل مع زيادة الميل المنحدر الى اسفل).

باحث اول بمحطة اختبار الجرارات الصباحية ـ اسكندرية المزية معهد بحوث الهندسة الزراعية ـ مركز البحوث الزراعية ـ القاهرة 


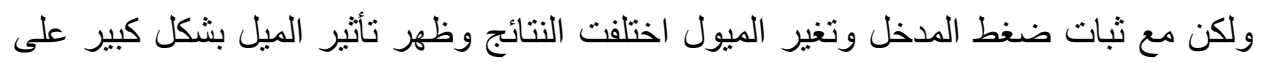

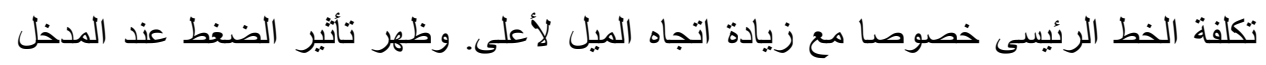
بتقليل التكاليف مع زيادة ضغط التشغيل.

ومع تحليل هذه النتائج نوصى بتطبيق طريقة البرمجة الخطية لتصميم خط الرش الرئيسى الرئي

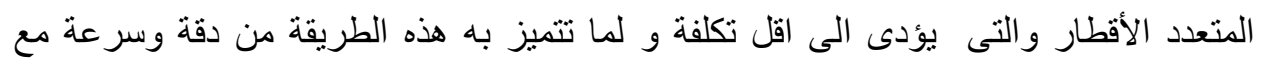
تطبيقات الحاسب الالى المتاحة لبرنامج اكسيل (Solver). 